\title{
Glutamic Acid Decarboxylase 67 mRNA Regulation in Two Globus Pallidus Neuron Populations by Dopamine and the Subthalamic Nucleus
}

\author{
Lauren M. Billings and John F. Marshall \\ Department of Neurobiology and Behavior, University of California, Irvine, California 92627-4550
}

\begin{abstract}
The globus pallidus (GP) consists of two neuron populations, distinguished according to their immunoreactivity for parvalbumin (PV). The PV-immunoreactive $(\mathrm{PV}+)$ neurons project preferentially to "downstream" targets such as the subthalamic and entopeduncular nuclei, whereas neurons lacking PV (PV - neurons) project preferentially to the striatum, suggesting a role for PV - cells in feedback to striatal neurons. Although dopamine D2 antagonist administration induces immediate early gene expression preferentially in PV- GP neurons, little is known about long-term regulation of PV - versus PV + GP neurons. Nigral 6-hydroxydopamine (6-OHDA) lesions or repeated D2-class antagonist injections have been shown to increase pallidal expression of glutamate decarboxylase $\left(\mathrm{GAD}_{67}\right.$ isoform) mRNA. This increase in $\mathrm{GAD}_{67}$ is believed to be secondary to activation of excitatory subthalamopallidal projections. The current study examined the effects of subthalamic nucleus (STN) lesion on 6-OHDA- or repeated D2 antagonist-induced changes in GP GAD ${ }_{67} \mathrm{mRNA}$ expression in PV + and PV - neurons. Five or $21 \mathrm{~d}$ after nigral 6-OHDA injections or after 3, 7, or $21 \mathrm{~d}$ of D2 antagonist administration, $\mathrm{GAD}_{67}$ mRNA increased in both the PV - and PV + GP neurons, but the magnitude of the increase was significantly greater in PVneurons. By contrast, STN lesion resulted in declines in $\mathrm{GAD}_{67}$ mRNA in both cell populations, with the decreases in PV+ neurons exceeding those in PV- neurons. Furthermore, STN lesion completely blocked 6-OHDA- or D2 antagonist-induced $\mathrm{GAD}_{67} \mathrm{mRNA}$ increases in $\mathrm{PV}+$ cells but only partly offset the $\mathrm{GAD}_{67} \mathrm{mRNA}$ increase in $\mathrm{PV}-$ pallidal neurons. Thus, the $\mathrm{PV}+$ and $\mathrm{PV}-$ neurons are influenced in qualitatively similar ways by dopamine and the STN, but these cell types exhibit contrasting degrees of regulation by the dopaminergic and STN perturbations. This pattern of results has implications for pallidal control of striatal versus downstream basal ganglia nuclei.
\end{abstract}

Key words: dopamine; GAD; globus pallidus (pallidum); Parkinson; substantia nigra; subthalamic nucleus

\section{Introduction}

Far from being a simple relay nucleus for striatal efference, the rodent globus pallidus (GP) is critically positioned to influence activity in all other basal ganglia structures (Staines et al., 1981; Smith and Bolam, 1990; Bevan et al., 1997; Sato et al., 2000). The GP is a heterogeneous structure (Kita, 1994; Rajakumar et al., 1994; Hoover and Marshall, 1999) whose neuron gene expression can be differentially regulated by pallidal afferent projections (Ruskin and Marshall, 1997; Hoover and Marshall, 2002; Billings and Marshall, 2003). The identification of distinct pallidal neuron populations has aided our understanding of this structure. In general, pallidal neurons that are retrogradely labeled from the subthalamic nucleus (STN) and the basal ganglia output nuclei contain the calcium-binding protein parvalbumin $(\mathrm{PV})$, whereas pallidal neurons retrogradely labeled from the striatum more fre-

Received July 30, 2003; revised Feb. 11, 2004; accepted Feb. 11, 2004.

The work was supported by National Institutes of Health (NIH) Grant NS-22698 (J.F.M). L.M.B. was supported by the Achievement Rewards for College Scientists Foundation and NIH Grant DA-15338 for graduate research. We thank Eddie Ibrahim for technical assistance with the in situ hybridizations.

Correspondence should be addressed to Dr. John F. Marshall, Department of Neurobiology and Behavior, University of California, 2205 McGaugh Hall, Irvine, CA 92627-4550. E-mail: jfmarsha@uci.edu.

D01:10.1523/JNEUROSCI.5118-03.2004

Copyright $\odot 2004$ Society for Neuroscience $\quad$ 0270-6474/04/243094-10\$15.00/0 quently contain the opioid precursor preproenkephalin (PPE) mRNA (Ruskin and Marshall, 1997; Hoover and Marshall, 1999, 2002). Parvalbumin and PPE rarely colocalize in pallidal neurons (Hoover and Marshall, 1999, 2002).

Although the GP receives moderate innervation by dopamine (DA) terminals (Fallon and Moore, 1978; Lindvall and Björklund, 1979), the function of dopamine in GP remains poorly understood. One suggestion is that DA acts presynaptically on D2-class receptors, decreasing GABA release from striatopallidal terminals (Floran et al., 1997; Cooper and Stanford, 2000). However, other pallidal responses are not easily reconciled with this suggestion. Systemic or intrapallidal administration of a D2-class antagonist induces Fos, the protein product of the immediate early gene (IEG) c-fos, almost exclusively in GP neurons that lack PV (Ruskin and Marshall, 1997; Billings and Marshall, 2003), findings not mimicked by intrapallidal application of a $\mathrm{GABA}_{\mathrm{A}}$ agonist.

An important unanswered question is whether these shortterm changes in IEG induction predict longer-term alterations in neurotransmitter-related gene expression within the relevant cell populations. Here we investigate changes in mRNA for the 67 $\mathrm{kDa}$ isoform of glutamic acid decarboxylase (GAD), the key enzyme in GABA neurotransmission within all GP neurons (Oertel 
and Mugnaini, 1984). Although previous studies have indicated that GP GAD ${ }_{67}$ mRNA levels increase after DA neuron degeneration or chronic dopamine receptor blockade (Kincaid et al., 1992; Soghomonian and Chesselet, 1992; Delfs et al., 1995a), no previous studies have examined this the regulation of this mRNA in specific GP cell populations.

The regulation of pallidal gene expression by DA appears also to involve the STN. Because STN lesions reverse 6-hydroxydopamine (6-OHDA) lesion-induced pallidal $\mathrm{GAD}_{67}$ mRNA increase, the $\mathrm{GAD}_{67}$ mRNA increase after 6-OHDA lesions may be triggered by increased subthalamopallidal activity (Delfs et al., 1995b). Therefore, 6-OHDA lesion-induced changes in GP late gene expression may result from a combination of increased subthalamopallidal glutamatergic input and decreased nigropallidal dopaminergic input, influences that could vary depending on pallidal cell type. Because previous work (Ruskin and Marshall, 1997; Hoover and Marshall, 2002; Billings and Marshall, 2003) demonstrated that $\mathrm{PV}-/ \mathrm{PPE}+$ pallidostriatal neurons are selectively sensitive to dopaminergic D2 antagonism, this population of neurons provides the most likely site for DA-glutamate interactions.

This study explores the population specificity of pallidal $\mathrm{GAD}_{67}$ mRNA regulation after 6-OHDA lesion or repeated dopamine antagonist administration. In light of those findings, we also examined the effects of STN lesions on these changes in $\mathrm{GAD}_{67}$ mRNA in $\mathrm{PV}+$ and $\mathrm{PV}-$ pallidal neurons.

\section{Materials and Methods}

Adult male Sprague Dawley rats $(n=190$; Charles River Laboratories, Hollister, CA) weighing 200-275 gm at the beginning of the experiment were individually housed and kept on a $12 \mathrm{hr}$ light/dark schedule. All rats were given ad libitum access to food and water. Experiments were performed during the light portion of the diurnal cycle. All animal procedures were in accordance with the National Institutes of Health Guide for the Care and Use of Laboratory Animals, and all appropriate measures were taken to minimize pain and discomfort in experimental animals.

\section{Experiment 1: nigral 6-hydroxydopamine lesions}

For the nigral DA cell lesions, rats $(n=22)$ weighing $200-250 \mathrm{gm}$ at the time of surgery were anesthetized with Equithesin ( $10 \mathrm{~mm}$ sodium pentobarbital, $256.8 \mathrm{~mm}$ chloral hydrate, $86 \mathrm{~mm} \mathrm{MgSO}_{4}, 10.5 \%$ propylene glycol, and $12 \%$ ethanol, administered at $4.2 \mathrm{mg} / \mathrm{kg}$, i.p.) and placed in a Kopf stereotaxic apparatus. Eight micrograms of 6-OHDA hydrobromide ( $\mathrm{HBr}$ ) (as base; Sigma, St. Louis, MO) dissolved in $4 \mu \mathrm{l}$ of $0.1 \%$ ascorbic acid in $0.9 \%$ saline $(n=16)$ or the vehicle $(n=6)$ were injected into the left ventral tegmentum through a 28 gauge cannula at $+2.6 \mathrm{~mm}$ from the interaural plane, $+1.0 \mathrm{~mm}$ from midline, and $-7.8 \mathrm{~mm}$ from dura. Vehicle injections (saline) were $-6.8 \mathrm{~mm}$ from dura to prevent nonspecific damage to the substantia nigra attributable to cannula penetration. Thirty minutes before the 6-OHDA $\mathrm{HBr}$ or vehicle infusion, desipramine $\mathrm{HCl}$ (Sigma; $15 \mathrm{mg} / \mathrm{kg}$, i.p., as base) was administered to each animal to antagonize the uptake of the 6-OHDA $\mathrm{HBr}$ into norepinephrine-containing cells or in sham lesion animals to serve as a control for the effects of desipramine alone. Animals in this study were perfused, as described below, 5 or $21 \mathrm{~d}$ after lesion (eight lesioned animals and three sham-lesioned animals at each time point). Tyrosine hydroxylase $(\mathrm{TH})$ immunocytochemistry was performed on coronal sections through the substantia nigra pars compacta $(\mathrm{SNc})$ from these animals to verify the extent of dopamine cell loss in 6-OHDA-lesioned animals. All animals included in the study had fewer than five TH-immunoreactive cells in each section of the SNc examined (Fig. 1D). No damage was noted in the uninjected hemisphere (Fig. 1C).

\section{Experiment 2: repeated dopamine antagonist injections}

For the repeated injection study, rats $(n=72)$ weighing $250-275 \mathrm{gm}$ at the beginning of the experiment were injected with the D2-class antagonist eticlopride (Research Biochemicals, St. Louis, MO; $1 \mathrm{mg} / \mathrm{kg}$, s.c.; $n=$
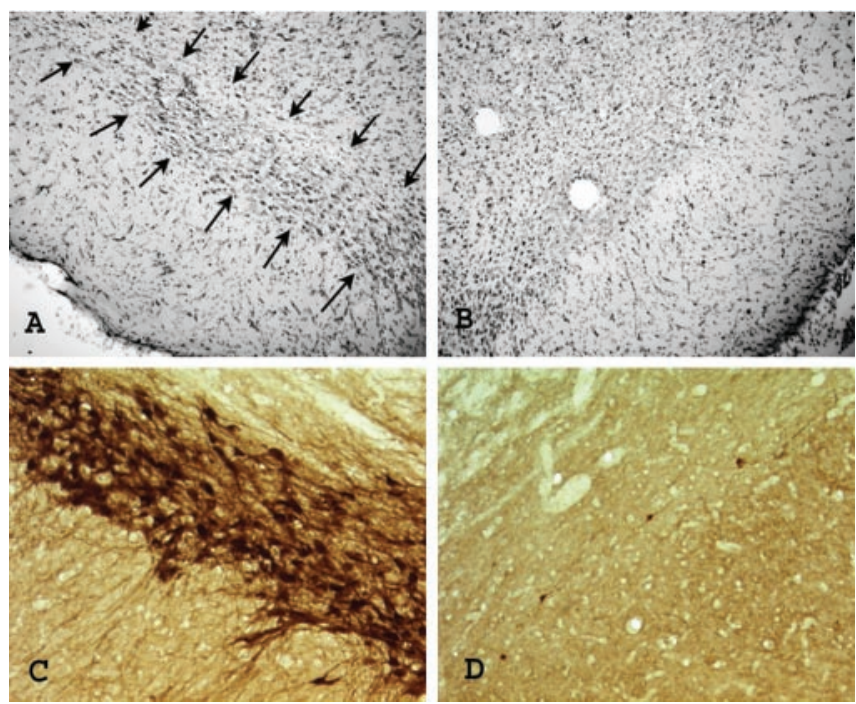

Figure 1. Photomicrographs of cresyl violet-stained sections of the STN of intact $(A)$ and kainic acid-lesioned $(B)$ animals and of TH-immunoreactive neurons in the SNc of intact $(C)$ and 6-OHDA-lesioned ( $D$ ) animals. In $A$, arrows denote the borders of the STN. Note the gliosis in $B$ and the lack of intact STN neurons. Also note the near total lack of TH-immunoreactive neurons in $D$.

$24)$, the D1-class antagonist $R(+/-)$-7-chloro-8-hydroxy-3-methyl-1phenyl-2,3,4,5-tetrahydro-1H-3-benzazepine maleate (SCH-23390) (Schering Corp., Bloomfield, NJ; $1 \mathrm{mg} / \mathrm{kg} ; n=24)$, or saline $(1 \mathrm{ml} / \mathrm{kg}$; $n=24)$ for 3,7 , or $21 \mathrm{~d}$ ( $n=8$ at each time point). All animals were perfused, as described below, $24 \mathrm{hr}$ after the last injection.

\section{Experiments 3 and 4: combined subthalamic nucleus lesion and} 6-OHDA or repeated D2 antagonist administration

STN lesion and 6-hydroxydopamine lesion study. For the subthalamic nucleus lesions, rats $(n=32)$ weighing $250-275 \mathrm{gm}$ at the time of surgery were anesthetized with Equithesin (4.2 ml/kg, i.p.) and placed in a Kopf sterotaxic apparatus. Animals receiving STN lesions $(n=16)$ received 0.3 $\mu \mathrm{g}$ of kainic acid dissolved in $0.1 \mu \mathrm{l}$ of $0.9 \%$ sterile saline into the left subthalamic nucleus at $+5.1 \mathrm{~mm}$ from interaural, $+2.6 \mathrm{~mm}$ from midline, and $-7.4 \mathrm{~mm}$ ventral to dura. Sham animals $(n=16)$ received an equal amount of sterile saline at the same coordinates, except the dorsalventral coordinate was adjusted to -6.4 ventral to dura to avoid damage to the subthalamic nucleus attributable to cannula penetration. Animals were allowed to recover for $6 \mathrm{~d}$ in their home cages before receiving a 6-OHDA $(n=16)$ or sham lesion $(n=16)$ of the SNc as described above.

Of the 32 animals in this study, 8 received an STN lesion and 6-OHDA lesion (LL group); 8 received an STN lesion and a sham SNc lesion (LS group); 8 received a sham STN lesion and a 6-OHDA SNc lesion (SL group); and 8 received sham lesions in both structures (SS group). Five days after the 6-OHDA or sham SNc lesion, animals were transcardially perfused as described below.

All animals included in the LS and LL groups had complete STN lesions as verified with cresyl violet staining of sections through the entire STN (Fig. 1B). No damage was noted in the contralateral STN (Fig. 1A). All animals included in the SL and LL groups had fewer than five THimmunoreactive cells in every SNc section examined. No damage was noted in the unlesioned hemisphere.

STN lesion and repeated injection study. For the combined STN lesion and repeated injection study, rats $(n=64)$ weighing $250-275 \mathrm{gm}$ at the beginning of the experiment were given an STN lesion $(n=32)$ or a sham lesion $(n=32)$ as described above and allowed $6 \mathrm{~d}$ to recover after the lesion. Then animals were injected twice daily with the D2 antagonist eticlopride (Research Biochemicals; $1 \mathrm{mg} / \mathrm{kg}$, s.c.; $n=32$ ), or saline (1 $\mathrm{ml} / \mathrm{kg} ; n=32$ ) for 3 or $7 \mathrm{~d}$. Therefore, there were eight groups in this study: STN lesion combined with $3 \mathrm{~d}$ eticlopride (L-3E) or $3 \mathrm{~d}$ saline (L-3V); sham STN lesion combined with 3 d eticlopride (S-3E) or $3 \mathrm{~d}$ saline (S-3V); STN lesion combined with $7 \mathrm{~d}$ eticlopride (L-7E) or $7 \mathrm{~d}$ 
saline (L-7V); and sham STN lesion combined with $7 \mathrm{~d}$ eticlopride (S-7E) or $7 \mathrm{~d}$ saline (S-7V). All groups consisted of eight animals. All animals were perfused, as described below, $24 \mathrm{hr}$ after the last injection.

\section{Tissue processing}

At their respective time points, animals from each study were transcardially perfused with ice-cold $0.1 \mathrm{M}$ PBS $(60 \mathrm{ml})$ followed by $4 \%$ paraformaldehyde $(120 \mathrm{ml})$. After perfusion, the brains were rapidly removed and postfixed overnight in $4 \%$ paraformaldehyde, followed by cryoprotection for $24 \mathrm{hr}$ in $30 \%$ sucrose in $0.1 \mathrm{M}$ phosphate buffer (PB). Coronal sections $(30 \mu \mathrm{m})$ through the GP were cut on a sliding microtome. GP sections were taken $0.4-1.1 \mathrm{~mm}$ caudal to bregma (Paxinos and Watson, 1998), which includes the GP regions most relevant to defined characteristics of basal ganglia circuitry (Shammah-Lagnado et al., 1996). All sections were stored in sterile $0.1 \mathrm{M}$ PB until being processed for $\mathrm{GAD}_{67}$ mRNA in situ hybridization later the same day. Tissue was processed through free-floating in situ hybridization using a $2.1 \mathrm{~kb} \mathrm{GAD}_{67}$ antisense riboprobe transcribed in the presence of $\left[{ }^{35} \mathrm{~S}\right] \mathrm{UTP}$ with a T7 RNA polymerase promoter. The $\mathrm{GAD}_{67} \mathrm{cDNA}$ was kindly donated by Dr. A. Tobin (University of California, Los Angeles, CA). Hybridization procedures consisted of sequentially rinsing the tissue in $0.75 \%$ glycine in $0.1 \mathrm{M} \mathrm{PB}$, $0.1 \mathrm{M} \mathrm{PB}, 0.25 \%$ acetic anhydride in $0.1 \mathrm{~m}$ triethanolamine, $2 \times \mathrm{SSC}$, a series of ascending and descending alcohols, and chloroform treatment. Sections were then immersed in hybridization buffer that contained the ${ }^{35}$ S-labeled riboprobe at a density of $15,000 \mathrm{cpm} / \mu \mathrm{l}$. Hybridization was performed overnight at $55^{\circ} \mathrm{C}$. Sections were then washed through two formamide and SSC rinses followed by an RNase buffer and RNase A treatment $(20 \mathrm{mg} / \mathrm{ml})$ and SSC rinses. Immediately subsequent to the $\mathrm{GAD}_{67}$ mRNA in situ hybridization, the tissue was processed for PV immunocytochemistry. The sections were incubated in $5 \%$ normal horse serum (NHS; Vector Laboratories, Burlingame, CA) followed by incubation in 1\% NHS (Vector Laboratories) containing an anti-PV monoclonal antibody (1:1000; Sigma) for $48 \mathrm{hr}$ at $4^{\circ} \mathrm{C}$. Sections were then incubated with a biotinylated horse anti-mouse secondary antibody (1:200, 2 $\mathrm{hr}$ at room temperature; Jackson ImmunoResearch, West Grove, PA), followed by avidin-biotin-peroxidase complex (1 hr; Vector Laboratories). PV was visualized by using 6\% 3,3'-diaminobenzidine (Pierce, Rockford, IL), and sections were then rinsed in $0.1 \mathrm{~m}$ Tris buffer and mounted on gelatin-coated slides. Two slides per animal to be used in analysis were dipped in NTB-2 emulsion (Eastman Kodak Co., Rochester, NY) for 5-8 d; one slide per animal was packed for $2 \mathrm{~d}$ against Raymax $\beta$ film to gauge the strength of the in situ hybridization signal to determine how longs slides should be kept in emulsion. Film and slides were developed with Kodak D-19, and slides were counterstained with hematoxylin-eosin (H\&E) and coverslipped.

\section{Tissue analysis}

Fields in the GP were imaged at an optical magnification of $400 \times$ using an Optiphot microscope (Nikon, Mellville, NY) interfaced to a microcomputer imaging device image analysis system (Imaging Research, St. Catherines, Ontario, Canada) calibrated to quantify the density of silver grains (representative of ${ }^{35} \mathrm{~S}_{-} \mathrm{GAD}_{67} \mathrm{mRNA}$ ) and to assess their association with $\mathrm{PV}+$ neurons. Because parvalbumin is not distributed equally throughout the GP (Rajakumar et al., 1994), the GP was subdivided into 12 equally sized regions at approximately $-0.92 \mathrm{~mm}$ from bregma (Paxinos and Watson, 1998) (see Fig. 3). Two channels were linked in the image analysis system. The first channel contained a bright-field image of one of the 12 regions in the GP. This channel was linked to a second channel that contained a dark-field representation of the same brightfield image. Using a sampling tool that was slightly larger than the largest $\mathrm{PV}+$ neuron in each sector, cells were selected in bright field to allow identification of whether they were $\mathrm{PV}+$, and the computer performed the grain counts in the corresponding dark-field channel (grains appeared as white pixels on a black screen). All neurons in each field (both $\mathrm{PV}+$ and H\&E-only) were quantified. (Pixel densities associated with 95-110 GP cells were collected for each animal or hemisphere.) Background levels of grain density were determined for each animal by using the sampling tool (of a size similar to the size described above) to measure pixel densities over the corpus callosum (for a total of 30 background readings per animal).

\section{Statistical analysis}

For all experiments, statistical analyses determined whether (1) $\mathrm{GAD}_{67}$ mRNA increased in pallidal neurons of treated animals (Kincaid et al., 1992; Soghomonian and Chesselet, 1992; Delfs et al., 1995a), (2) any such increase occurred in predominantly $\mathrm{PV}+$ or PV - pallidal neurons, (3) the duration of dopamine antagonist treatment or the interval since 6-OHDA infusion affected any cell population specificity of changes in $\mathrm{GAD}_{67}$ mRNA expression, and (4) any changes in pallidal $\mathrm{GAD}_{67} \mathrm{mRNA}$ expression differed by GP region. $\mathrm{GAD}_{67}$ mRNA (pixels per cell) was measured, and numbers were collapsed into a quadrant value (see Fig. 3).

For all groups, initial repeated measures ANOVA indicated there were no within-subjects regional differences. Consequently, the values for each quadrant were summed and collapsed into one value for $\mathrm{PV}+$ and another value for PV- pallidal neurons for each animal. All further statistical analyses were conducted using these values. Repeated measures ANOVAs and subsequent simple main effects analyses were used to determine differences in $\mathrm{GAD}_{67}$ mRNA expression with respect to treatment condition (or hemisphere) or cell type specificity.

Because substantial differences in the absolute values of $\mathrm{GAD}_{67} \mathrm{mRNA}$ were found between the two in situ hybridization reactions for experiment 1 (presumably because of differences in emulsion coating resulting in higher levels of $\mathrm{GAD}_{67}$ mRNA and background labeling or other unknown variations in the hybridization), an initial repeated measures ANOVA with a single within-subject factor (hemisphere) was used to establish a main effect of lesion for this study. This ANOVA included "background readings" from the corpus callosum as a covariate (ANCOVA). To analyze the differences in $\mathrm{GAD}_{67}$ mRNA levels in the two pallidal neuron cell types as well as to analyze any group effects, values were normalized to "percent increase from unlesioned hemisphere" for each cell type in each GP quadrant. No regional differences were noted with these values; they were therefore collapsed into a single value for $\mathrm{PV}+$ and one for PV - GP neurons.

For experiment 2, one-way ANOVAs and post hoc Scheffé tests were used to explore differences between time points. For experiment 4, comparisons between groups ( 3 and $7 \mathrm{~d}$ injection groups) were made using independent sample $t$ tests. In all statistical comparisons, the dependent variable was $\mathrm{GAD}_{67}$ mRNA expression, unless otherwise noted. All values were considered significantly different at a $p<0.05$ level.

\section{Results}

\section{$\mathrm{GAD}_{67}$ mRNA labeling}

$\mathrm{GAD}_{67}$ mRNA labeling was found in punctate clusters that overlaid PV + neurons, H\&E-counterstained neurons, or both (Fig. 2; see Fig. 6). A group of silver grains was considered a cluster if $>10$ pixels were contained within the sampling tool area, although clusters in this study contained at least 25 pixels per cell. Callosal pixel levels were well below cellular labeling levels (data not shown). Parvalbumin-positive neurons were easily identified by distinct brown labeling of the entire soma as well as neuronal processes. Neurons labeled by H\&E stain only (i.e., PV- neurons) had clear, purple nuclei; glial cells labeled with $\mathrm{H} \& \mathrm{E}$ had dark, very small nuclei and were not included in the quantification. Soma size was used as an additional criterion for distinguishing glia from neurons when nuclear staining was questionable. Although PV + cells are slightly larger than PV - cells, both types are substantially larger than glial cells. All $\mathrm{GAD}_{67}$ mRNA quantification of silver grains was carried out under dark-field illumination, and identification of cells was performed under bright-field illumination.

\section{Experiment 1: nigral 6-hydroxydopamine lesions}

The first experiment examined the effects of nigral 6-OHDA injections on $\mathrm{GAD}_{67}$ mRNA expression in $\mathrm{PV}+$ and $\mathrm{PV}-$ neurons 5 and $21 \mathrm{~d}$ postoperatively. Overall $\mathrm{GAD}_{67}$ mRNA levels were found to be significantly greater in the GP of the 6-OHDAinjected compared with uninjected hemispheres [ANCOVA; 

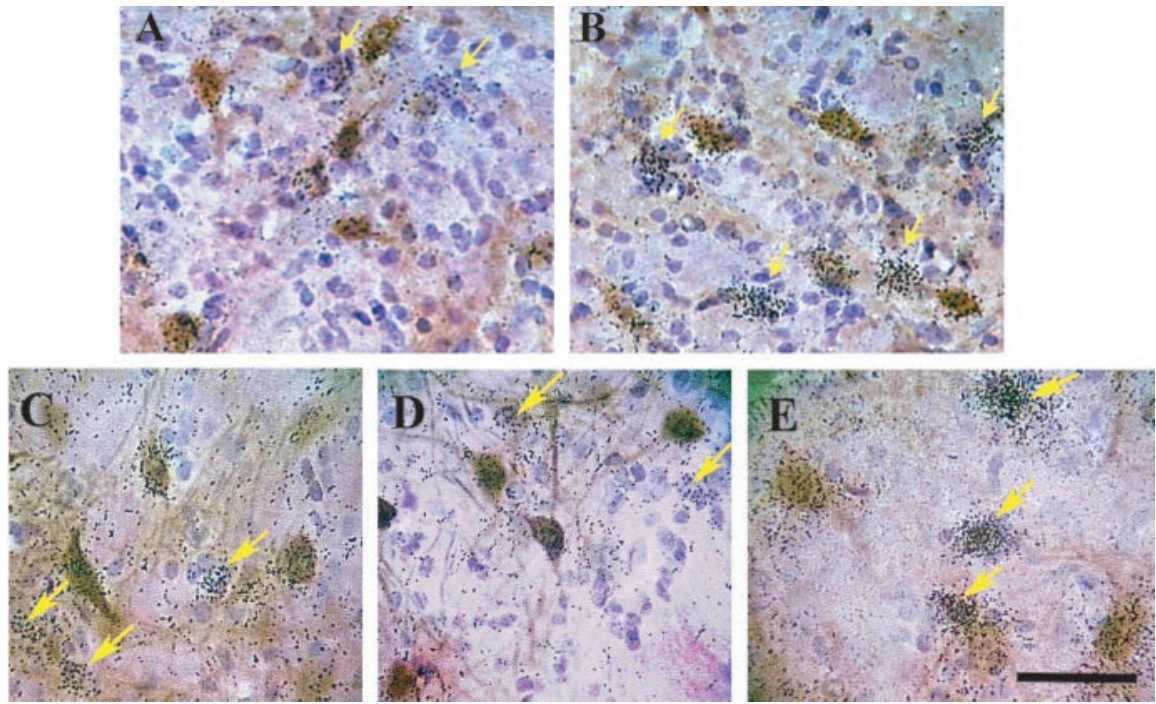

Figure 2. Photomicrograph of $\mathrm{GAD}_{67} \mathrm{mRNA}$ in PV + (brown cells) and PV - (yellow arrowheads) GP neurons of animals in experiment $1(A, B)$ and experiment $2(C-E)$. $A, B$, The unlesioned hemisphere is depicted in $A$, and the lesioned hemisphere is depicted in $B$. Note the increase in $\mathrm{GAD}_{67} \mathrm{mRNA}$ in the lesioned hemisphere overall and the more pronounced increase in PV - GP neurons compared with PV + GP neurons. $C-E, G A D_{67}$ mRNA in PV + (brown cells) and PV - (yellow arrows) GP neurons in vehicle-treated $(C)$, SCH-23390-treated $(D)$, and eticlopride-treated $(E)$ animals. Note the eticlopride-induced increase in $G_{6 D}$ mRNA overall and the more pronounced increase in $\mathrm{GAD}_{67} \mathrm{mRNA}$ in PV - compared with PV + GP neurons. Scale bar, $50 \mu \mathrm{m}$.

$\left[F_{(1,21)}=5287.6 ; p<0.001\right]$, with the $\mathrm{GAD}_{67}$ mRNA levels in both cell types of eticlopride-treated animals being elevated relative to SCH-23390-treated $\left[F_{(1,21)}=\right.$ $11769.2 ; p<0.001$ for $\mathrm{PV}+$ neurons; $F_{(1,21)}=16589.2 ; p<0.001$ for PV - neurons $]$ or vehicle-treated animals $\left[F_{(1,21)}=\right.$ $11137.9 ; p<0.001$ for $\mathrm{PV}+$ neurons; $F_{(1,21)}=15626.3 ; p<0.001$ for PV - neurons]. In addition, after $7 \mathrm{~d}$ of treatment, $\mathrm{GAD}_{67}$ mRNA levels in both cell populations of SCH-23390-treated animals were significantly lower than $\mathrm{GAD}_{67}$ mRNA levels in corresponding cell types of vehicle-treated controls $\left[F_{(1,21)}=8.7 ; p<\right.$ 0.01 for $\mathrm{PV}+$ neurons; $F_{(1,21)}=14.4 ; p<$ 0.01 for $\mathrm{PV}-$ neurons].

In animals injected for $7 \mathrm{~d}, \mathrm{GAD}_{67}$ mRNA levels differed between $\mathrm{PV}+$ and PV - cell types $\left[F_{(1,21)}=218.9 ; p<0.001\right]$, and a significant treatment $\times$ cell type interaction was observed $\left[F_{(2,21)}=198.5\right.$; $p<0.001]$. In the group receiving eticlopride, $\mathrm{GAD}_{67}$ mRNA levels in $\mathrm{PV}-\mathrm{GP}$ neurons were significantly higher than in $\mathrm{PV}+\mathrm{GP}$ neurons $\left[F_{(1,21)}=574.7 ; p<\right.$

$F_{(1,13)}=102.8 ; p<0.001$; Fig. 3]. $\mathrm{GAD}_{67}$ mRNA was markedly increased in both the PV - and $\mathrm{PV}+$ cells, and subsequent ANOVA using the normalized (percentage) values indicated that $\mathrm{GAD}_{67}$ mRNA levels were significantly higher in the PV - than PV + cells $\left[F_{(1,14)}=29.9 ; p<0.001 ;\right.$ Fig. 3]. However, neither a significant effect of days after lesion (group) nor a group $\times$ cell type interaction was detected.

\section{Experiment 2: repeated dopamine antagonist injections}

In the second experiment, animals received twice daily injections of the D2-class antagonist eticlopride, the D1-class antagonist SCH-23390, or the saline vehicle for 3, 7, or $21 \mathrm{~d}$. Tissue was processed for $\mathrm{GAD}_{67} \mathrm{mRNA}$ in situ hybridization followed by PV immunocytochemistry.

\section{Three day treatment}

In animals injected for $3 \mathrm{~d}$, the drug treatment condition (eticlopride, SCH-23390, or vehicle) significantly affected pallidal $\mathrm{GAD}_{67}$ mRNA expression $\left[F_{(1,21)}=7038.9 ; p<0.001\right.$; Fig. 4$]$. For both cell types, $\mathrm{GAD}_{67}$ mRNA levels in eticlopride-treated animals were higher than in SCH-23390-treated animals $\left[F_{(1,21)}\right.$ $=2010.6 ; p<0.001$ for PV+ neurons; $F_{(1,21)}=2145.2 ; p<0.001$ for PV - neurons $]$ or vehicle-treated animals $\left[F_{(1,21)}=1907.9\right.$; $p<0.001$ for PV + neurons; $F_{(1,21)}=2276.1 ; p<0.001$ for PV neurons]. Moreover, $\mathrm{GAD}_{67}$ mRNA levels between SCH-23390and vehicle-treated animals did not differ for either cell type.

ANOVA also revealed a significant effect of cell type $\left[F_{(1,21)}=\right.$ 11.6; $p<0.01]$ as well as a significant drug treatment $\times$ cell type interaction $\left[F_{(2,21)}=4.2 ; p<0.05\right]$. Animals treated with eticlopride for $3 \mathrm{~d}$ had significantly higher levels of $\mathrm{GAD}_{67} \mathrm{mRNA}$ in $\mathrm{PV}-$ than in PV + GP neurons $\left[F_{(1,21)}=14.4 ; p<0.01\right]$, but the levels of $\mathrm{GAD}_{67}$ mRNA in $\mathrm{PV}+$ and $\mathrm{PV}-$ pallidal neurons in animals treated with SCH-23390 or vehicle did not differ.

\section{Seven day treatment}

A similar overall pattern was seen in animals treated with eticlopride, SCH-23390, or vehicle for $7 \mathrm{~d}$ (Fig. 4). The drug treatment condition significantly affected pallidal $\mathrm{GAD}_{67}$ mRNA levels
$0.001]$; by contrast, there were no cell population differences in animals treated for $7 \mathrm{~d}$ with SCH-23390 or vehicle. Figure 5 shows a frequency histogram of $\mathrm{GAD}_{67}$ mRNA distribution in $\mathrm{PV}+$ and $\mathrm{PV}-$ neurons of representative $7 \mathrm{~d}$ eticlopride and $7 \mathrm{~d}$ vehicle animals.

\section{Twenty-one day treatment}

A similar pattern was observed in animals treated for $21 \mathrm{~d}$ with eticlopride, SCH-23390, or vehicle (Fig. 4). The drug treatment condition significantly influenced pallidal $\mathrm{GAD}_{67}$ mRNA levels $\left[F_{(1,21)}=575.7 ; p<0.001\right]$, with $\mathrm{GAD}_{67}$ mRNA levels being significantly higher in both cell populations of eticlopride-treated animals compared with SCH-23390-treated animals $\left[F_{(1,21)}=\right.$ $380.9 ; p<0.001$ for PV+ neurons; $F_{(1,21)}=2421.4 ; p<0.001$ for $\mathrm{PV}-$ neurons $]$ or vehicle-treated groups $\left[F_{(1,21)}=400.3 ; p<\right.$ 0.001 for $\mathrm{PV}+$ neurons; $F_{(1,21)}=2398.2 ; p<0.001$ for $\mathrm{PV}-$ neurons]. The $\mathrm{GAD}_{67}$ mRNA levels of SCH-23390- and vehicletreated animals did not differ.

In addition, ANOVA revealed a significant effect of cell type $\left[F_{(1,21)}=98.3 ; p<0.001\right]$ as well as a significant treatment $\times$ cell type interaction $\left[F_{(2,21)}=110.4 ; p<0.001\right]$ in animals treated for 21 d. Although no population differences occurred in $\mathrm{SCH}$ 23390- or vehicle-treated animals, $\mathrm{GAD}_{67}$ mRNA in eticlopridetreated animals was significantly higher in $\mathrm{PV}-$ than $\mathrm{PV}+$ pallidal neurons $\left[F_{(1,21)}=533.1 ; p<0.001\right]$.

\section{Comparisons between time points}

Additional comparisons revealed that overall pallidal $\mathrm{GAD}_{67}$ mRNA levels of eticlopride-treated animals differed across the time span of the treatments $\left[F_{(2,23)}=1313.3 ; p<0.001\right]$. Post hoc Scheffé tests indicated that $\mathrm{GAD}_{67}$ mRNA levels after both 3 and $21 \mathrm{~d}$ of eticlopride administration were lower than after $7 \mathrm{~d}$ of this treatment.

Because overall $\mathrm{GAD}_{67}$ mRNA levels vary between each injection group, and because population differences emerged at all three time points in eticlopride-treated animals, it was important to determine whether differences between $\mathrm{PV}+$ and $\mathrm{PV}-$ palli- 

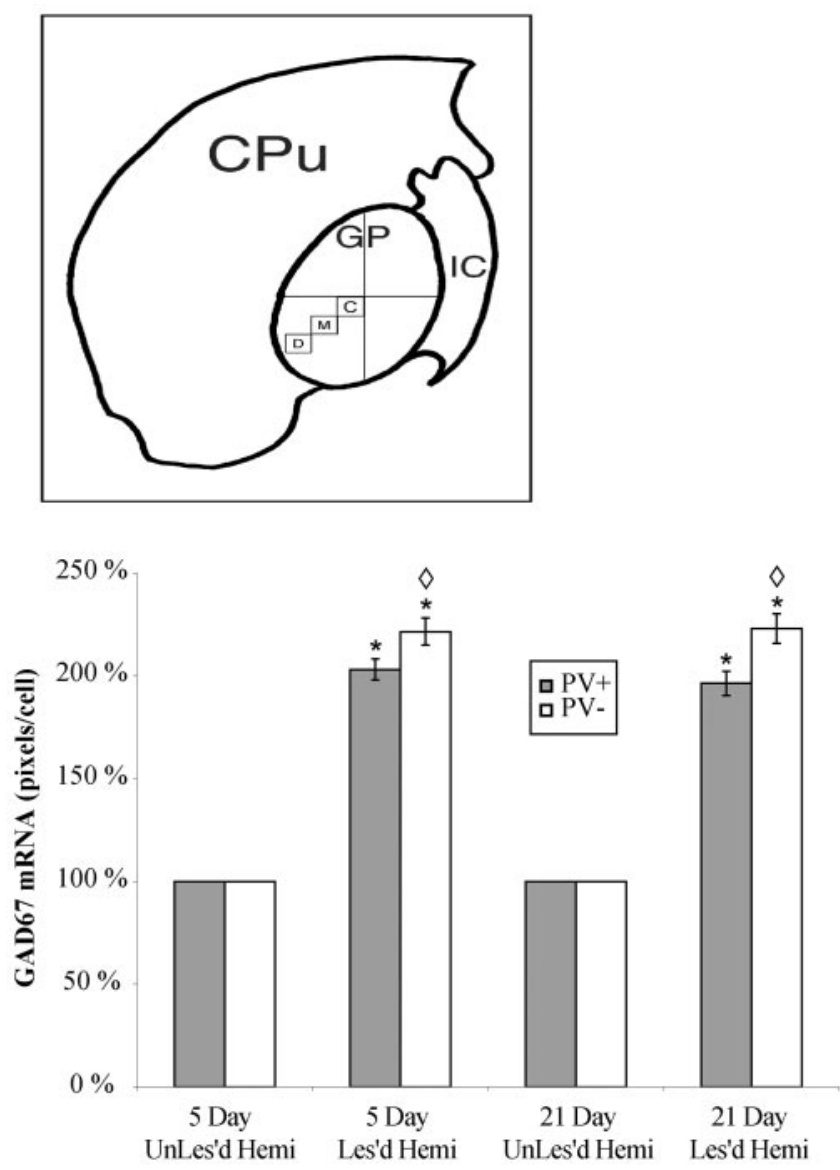

Figure 3. 6-OHDA lesion-induced increases in $\mathrm{GP}_{\mathrm{GAD}} \mathrm{G}_{67} \mathrm{mRNA}$ expression. Although 6-OHDA lesion increased $\mathrm{GAD}_{67}$ mRNA expression in both PV + and PV - GP neurons when compared with the unlesioned hemisphere $(*)$, at both times ( 5 and $21 \mathrm{~d}$ ), this increase was more pronounced in PV - GP neurons than PV + GP neurons $(\diamond)$. Note that this graph is expressed as percent increase from unlesioned hemisphere attributable to differences in background (and subsequent $\mathrm{GAD}_{67}$ mRNA labeling) between the in situ runs. No differences were found between the initial measured values of $\mathrm{GAD}_{67}$ mRNA expression in PV + and PV - neurons in the unlesioned hemisphere; $n=8$ for all groups. Les'd Hemi; Lesioned hemisphere; UnLes'd Hemi, unlesioned hemisphere. CPu, Caudate putamen; $C$, central sector; M, medial sector; D, distal sector; IC, internal capsule.

dal $\mathrm{GAD}_{67}$ mRNA levels in eticlopride-treated animals varied at the three time points. To examine this possibility, difference scores were computed for each eticlopride-treated animal (PVvalues $-\mathrm{PV}+$ values) at each of the three time points. ANOVA revealed a significant difference between these difference scores for the three time points $\left[F_{(2,23)}=56.8 ; p<0.001\right]$. Post hoc Scheffé tests revealed that, whereas $3 \mathrm{~d}$ eticlopride-treated animals had significantly smaller difference scores than 7 or $21 \mathrm{~d}$ eticlopride-treated animals, the 7 and 21 d groups did not differ. Therefore, although overall $\mathrm{GAD}_{67}$ mRNA levels were significantly lower in $21 \mathrm{~d}$ animals than in $7 \mathrm{~d}$ eticlopride-treated animals, the cell population difference was maintained for at least 3 weeks postoperatively (see Fig. 4).

Experiments 3 and 4: combined subthalamic nucleus lesion and 6-OHDA or repeated D2 antagonist administration

Experiment 3: combined STN lesion and 6-hydroxydopamine lesion

Animals received a subthalamic nucleus or sham lesion followed 6 d later by a SNc 6-OHDA or sham (vehicle) lesion, yielding four groups: LL, LS, SL, and SS. No differences were noted in $\mathrm{GAD}_{67}$
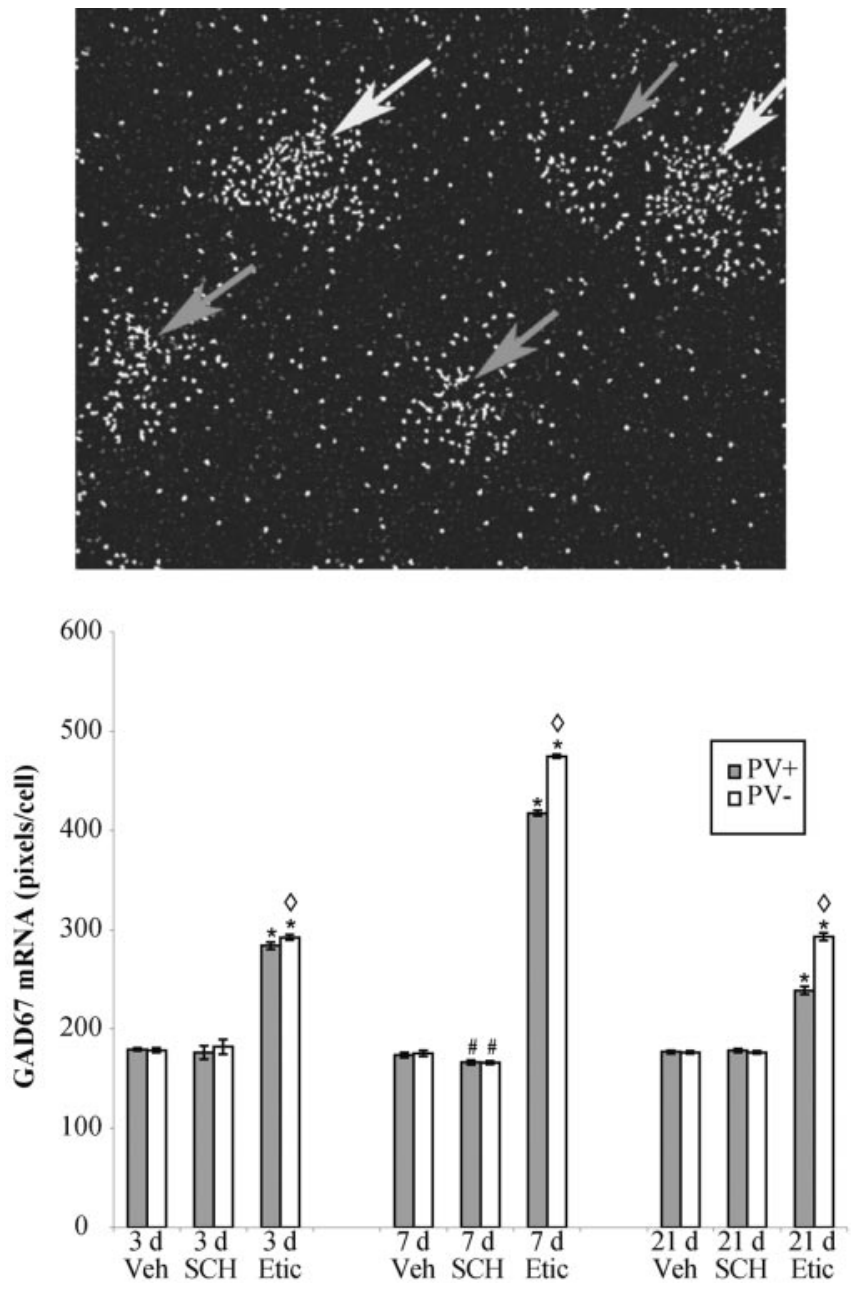

Figure 4. Repeated administration of the $\mathrm{D} 2$ antagonist eticlopride (Etic) increases $\mathrm{GAD}_{67}$ mRNA more markedly in PV - than PV + GP neurons. Although $\mathrm{GAD}_{67}$ mRNA expression increased in both PV + and PV - GP neurons when compared with vehicle (Veh) controls $\left(^{*}\right)$, this increase was more pronounced in PV - GP neurons when compared to PV + GP neurons $(\diamond)$. In addition, at $7 \mathrm{~d}$, $\mathrm{SCH}-23390$ (SCH)-treated animals had significantly lower $\mathrm{GAD}_{67} \mathrm{mRNA}$ expression levels when compared with vehicle controls (\#). No neuron population differences in $\mathrm{GAD}_{67} \mathrm{mRNA}$ expression were seen in animals treated with vehicle or the $\mathrm{D} 1$ antagonist $\mathrm{SCH}-$ $23390 ; n=8$ for all groups. Top panel, Dark-field photomicrograph showing silver grain clusters from a 7 d eticlopride-treated animal. Gray arrows indicate PV $+G P$ neurons, and white arrows indicate PV - GP neurons.

mRNA expression levels between PV + and PV - cells in the SS group.

Overall, clear trends were evident toward both 6-OHDAinduced increases and STN lesion-induced decreases in $\mathrm{GAD}_{67}$ mRNA, with the PV - and PV + cell populations being distinctly affected (Fig. 6). For both $\mathrm{PV}+$ and $\mathrm{PV}-$ pallidal neurons, ANOVA revealed a significant interaction between lesion type [LL, LS, SL, SS groups, $F_{(1,28)}=59.1 ; p<0.001$ for PV + cells; $F_{(1,28)}=116.9 ; p<0.001$ for PV - cells; Fig. 7]. $\mathrm{GAD}_{67} \mathrm{mRNA}$ levels in PV + cells were significantly lower in the LL group compared with the SS group $\left[F_{(1,14)}=11.1 ; p<0.01\right]$. By contrast, $\mathrm{GAD}_{67}$ mRNA levels in PV - pallidal neurons were significantly increased in the LL group compared with the SS group $\left[F_{(1,14)}=\right.$ 30.7; $p<0.001]$. Indeed, whereas the $\mathrm{GAD}_{67} \mathrm{mRNA}$ levels in $\mathrm{PV}+$ and $\mathrm{PV}-$ neurons of the SS group did not differ, $\mathrm{GAD}_{67}$ mRNA was significantly higher in $\mathrm{PV}-$ than $\mathrm{PV}+$ neurons of the LL group $\left[F_{(1,7)}=150.9 ; p<0.001\right]$.

As originally described by Delfs et al. (1995b), the STN lesion 

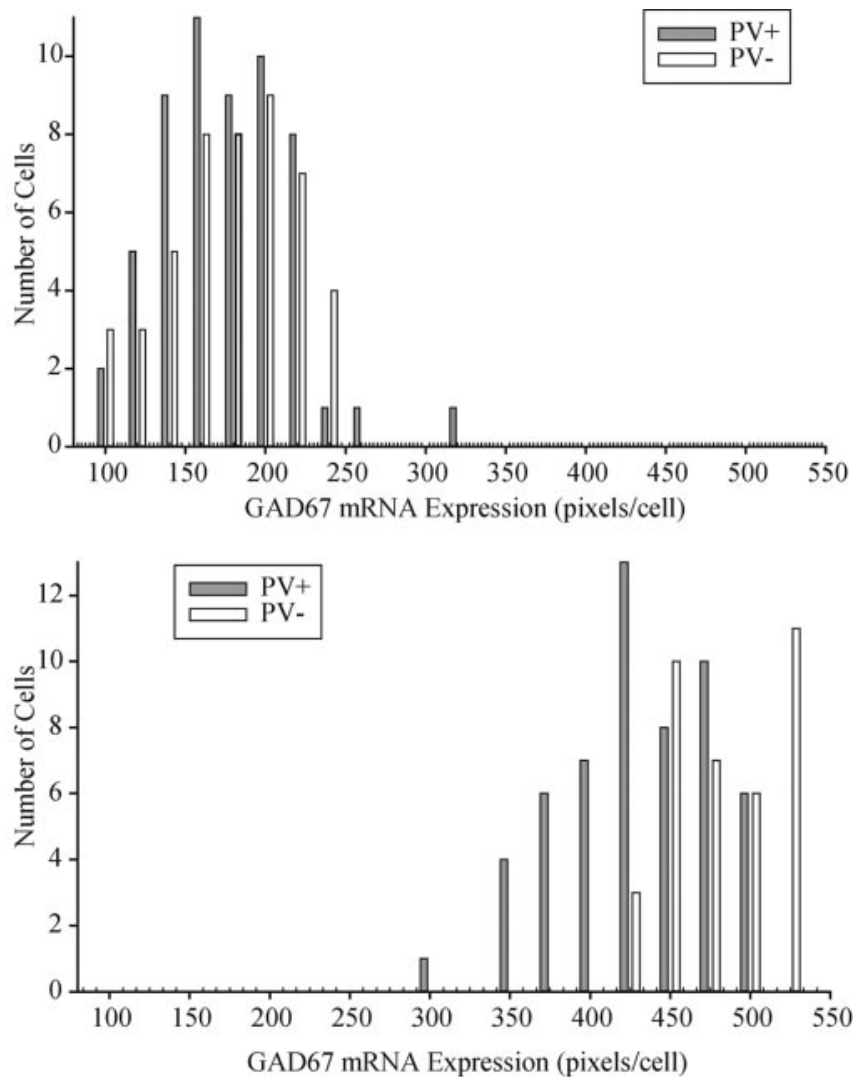

Figure 5. Frequency histograms demonstrating $\mathrm{GAD}_{67} \mathrm{mRNA}$ distribution in $\mathrm{PV}+$ and $\mathrm{PV}-$ cells of $7 \mathrm{~d}$ vehicle-treated (top) and $7 \mathrm{~d}$ eticlopride-treated (bottom) animals. Note (1) the overall increase in $\mathrm{GAD}_{67}$ mRNA and (2) the greater $\mathrm{GAD}_{67} \mathrm{mRNA}$ expression in PV - GP neurons with respect to PV+ GP neurons for the eticlopride-treated rat.

significantly affected pallidal $\mathrm{GAD}_{67}$ mRNA levels $\left[F_{(1,28)}=\right.$ $210.502 ; p<0.001$ for PV + cells; $F_{(1,28)}=227.370 ; p<0.001$ for $\mathrm{PV}-$ cells]. STN lesion alone (LS group) resulted in a slight decrease in $\mathrm{GAD}_{67}$ mRNA labeling in both GP cell populations when compared with sham controls [SS group, $F_{(1,14)}=20.4 ; p<$ 0.001 for $\mathrm{PV}+$ neurons; $F_{(1,14)}=9.5 ; p<0.01$ for PV - neurons $]$. This decline in $\mathrm{GAD}_{67}$ mRNA after STN lesion alone was more pronounced in $\mathrm{PV}+$ than in $\mathrm{PV}-$ pallidal neurons. Although $\mathrm{GAD}_{67}$ mRNA levels in PV + and PV - neurons of the SS group did not differ, $\mathrm{GAD}_{67}$ mRNA was significantly higher in PVthan PV+ neurons of the LS group $\left[F_{(1,7)}=16.0 ; p<0.01\right]$.

The SNc 6-OHDA lesion also significantly affected pallidal $\mathrm{GAD}_{67}$ mRNA levels $\left[F_{(1,28)}=137.0 ; p<0.001\right.$ for PV+ cells; $F_{(1,28)}=465.6 ; p<0.001$ for $\mathrm{PV}-$ cells]. As shown previously (Kincaid et al., 1992; Soghomonian and Chesselet, 1992) (experiment 1), an SNc 6-OHDA lesion alone (SL group) significantly increased $\mathrm{GAD}_{67} \mathrm{mRNA}$ in both GP cell populations compared with the sham control [SS group, $F_{(1,14)}=190.7 ; p<0.001$ for $\mathrm{PV}+$ neurons; $F_{(1,14)}=562.2 ; p<0.001$ for PV - pallidal neurons]. This 6-OHDA-induced increase in $\mathrm{GAD}_{67}$ mRNA was greater in $\mathrm{PV}-$ than $\mathrm{PV}+$ pallidal neurons. Although $\mathrm{GAD}_{67}$ mRNA levels in PV + and PV - neurons of the SS group did not differ, $\mathrm{GAD}_{67}$ mRNA was significantly higher in PV - than PV+ neurons of the SL group $\left[F_{(1,7)}=123.0 ; p<0.001\right]$.

Experiment. 4: combined STN lesion and repeated D2 antagonist injections

Animals received a subthalamic nucleus or sham lesion followed $6 \mathrm{~d}$ later by 3 or $7 \mathrm{~d}$ of twice-daily injections of the D2 antagonist eticlopride or vehicle saline. This yielded eight groups: L-3E, L-3V, S-3E, S-3V, L-7E, L-7V, S-7E, and S-7V. No differences were noted in $\mathrm{GAD}_{67}$ mRNA expression levels between $\mathrm{PV}+$ and $\mathrm{PV}-$ cells in the S-3V or S-7V groups.

Overall, clear trends were seen toward eticlopride-induced increases in $\mathrm{GAD}_{67}$ mRNA expression at both time points, as well as STN lesion-induced decreases in $\mathrm{GAD}_{67}$ mRNA, with the PV+ and PV - cell populations being distinctly affected (Figs. 6, 8). For groups given $3 \mathrm{~d}$ of treatment, ANOVA revealed a significant treatment $\times$ lesion interaction $\left[F_{(1,28)}=125.2 ; p<0.001\right.$ for $\mathrm{PV}+$ cells; $F_{(1,28)}=132.3 ; p<0.001$ for PV - cells; Fig. 8$]$. When compared with animals in the $\mathrm{S}-3 \mathrm{~V}$ group, animals in the $\mathrm{L}-3 \mathrm{E}$ group showed significantly decreased levels of $\mathrm{GAD}_{67}$ mRNA in $\mathrm{PV}+$ pallidal neurons $\left[F_{(1,14)}=14.1 ; p<0.01\right]$ but increased levels of $\mathrm{GAD}_{67} \mathrm{mRNA}$ expression in $\mathrm{PV}-$ pallidal neurons $\left[F_{(1,14)}=104.9 ; p<0.001\right]$. Indeed, $\mathrm{GAD}_{67}$ mRNA was significantly higher in $\mathrm{PV}-$ than $\mathrm{PV}+$ neurons in animals of the L-3E group $\left[F_{(1,7)}=136.4 ; p<0.001\right]$.

As in the previous experiment, the STN lesion significantly affected pallidal $\mathrm{GAD}_{67}$ mRNA in the two populations of cells $\left[F_{(1,28)}=723.7 ; p<0.001\right.$ for PV + cells; $F_{(1,28)}=203.1 ; p<$ 0.001 for PV - cells]. GAD ${ }_{67}$ mRNA levels in PV + pallidal neurons were lower in animals of the L-3V group compared with the $\mathrm{S}-3 \mathrm{~V}$ group $\left[F_{(1,14)}=84.6 ; p<0.001\right]$. By contrast, the $\mathrm{GAD}_{67}$ mRNA levels in PV - pallidal neurons of the L-3V and S-3V groups did not differ $\left[F_{(1,14)}=2.6 ; p>0.05\right]$. Indeed, $\mathrm{GAD}_{67}$ mRNA was significantly higher in $\mathrm{PV}-$ than $\mathrm{PV}+$ neurons of the L-3V group $\left[F_{(1,7)}=137.6 ; p<0.001\right]$. Therefore, the STN lesion alone appeared to preferentially affect the $\mathrm{PV}+$ pallidal neurons.

Also, the repeated drug treatment condition (eticlopride vs vehicle) significantly affected $\mathrm{GAD}_{67} \mathrm{mRNA}$ expression in both populations of pallidal neurons $\left[F_{(1,28)} 459.9 ; p<0.001\right.$ for $\mathrm{PV}+$ cells; $F_{(1,28)}=603.4 ; p<0.001$ for PV - cells $]$. $\mathrm{GAD}_{67}$ mRNA levels were significantly elevated in both $\mathrm{PV}+$ and $\mathrm{PV}-$ pallidal neurons of S-3E animals when compared with S-3V animals $\left[F_{(1,14)}=549.3 ; p<0.001\right.$ for $\mathrm{PV}+$ neurons; $F_{(1,14)}=1199.7 ; p<$ 0.001 for PV - neurons]. Simple effects comparisons indicated that $\mathrm{GAD}_{67}$ mRNA was significantly higher in PV - than PV+ neurons in S-3E animals $\left[F_{(1,7)}=36.1 ; p<0.001\right]$.

A similar analysis was conducted on $\mathrm{GAD}_{67}$ mRNA levels in GP sections derived from the $7 \mathrm{~d}$ treatment group. ANOVA revealed a significant lesion $\times$ treatment interaction for both cell types $\left[F_{(1,28)}=1085.5 ; p<0.001\right.$ for PV + neurons; $F_{(1,28)}=$ $1595.1 ; p<0.001$ for $\mathrm{PV}-$ neurons]. $\mathrm{GAD}_{67} \mathrm{mRNA}$ levels in tissue from L-7E animals differed significantly from $\mathrm{GAD}_{67}$ mRNA levels in corresponding cell types from S-7V animals: $\mathrm{GAD}_{67}$ mRNA levels in PV + cells in L-7E animals were significantly lower than $\mathrm{GAD}_{67}$ mRNA levels in S-7V PV+ cells $\left[F_{(1,14)}\right.$ $=6.9 ; p<0.05]$, whereas $\mathrm{GAD}_{67}$ mRNA levels in PV - pallidal neurons were significantly increased when compared with PVcells from S-7V-treated tissue $\left[F_{(1,14)}=136.2 ; p<0.001\right]$. Indeed, simple effects comparisons indicated that $\mathrm{GAD}_{67}$ mRNA was significantly higher in $\mathrm{PV}-$ than $\mathrm{PV}+$ neurons in L-7E animals $\left[F_{(1,7)}=236.7 ; p<0.001\right]$.

The STN lesion significantly affected pallidal $\mathrm{GAD}_{67} \mathrm{mRNA}$ in both $\mathrm{PV}+$ and $\mathrm{PV}-$ cell populations $\left[F_{(1,28)}=1989.4 ; p<0.001\right.$ for PV + cells; $F_{(1,28)}=1757.9 ; p<0.001$ for PV - cells $]$. Pallidal $\mathrm{PV}+\mathrm{GAD}_{67}$ mRNA levels were significantly lower in L-7V animals compared with S-7V animals $\left[F_{(1,14)}=54.8 ; p<0.001\right]$. By contrast, pallidal PV $-\mathrm{GAD}_{67} \mathrm{mRNA}$ levels of $\mathrm{L}-7 \mathrm{~V}$ animals were no different from those of S-7V animals $\left[F_{(1,14)}=1.5 ; p>0.05\right]$. Simple effects comparisons indicated that $\mathrm{GAD}_{67}$ mRNA was 
significantly higher in $\mathrm{PV}-$ than $\mathrm{PV}+$ neurons in L-7V animals $\left[F_{(1,7)}=36.2\right.$; $p<0.001$.

In addition, treatment of sham STNlesioned rats with eticlopride for $7 \mathrm{~d}$ increased $\mathrm{GAD}_{67}$ mRNA levels in both GP cell types $\left[F_{(1,28)}=1634.8 ; p<0.001\right.$ for $\mathrm{PV}+$ cells; $F_{(1,28)}=3414.0$ for PV - cells $]$. A simple main effects analysis revealed that, for S-7E animals, both cell types demonstrated dramatically increased levels of $\mathrm{GAD}_{67}$ mRNA when compared with S-7V controls $\left[F_{(1,14)}=1965.6 ; p<0.001\right.$ for $\mathrm{PV}+$ neurons; $F_{(1,14)}=5473.9 ; p<0.001$ for $\mathrm{PV}-$ neurons]. This increase at $7 \mathrm{~d}$ was significantly greater than the corresponding group increase in $3 \mathrm{~d}$ eticlopridetreated animals $\left(t_{(14)}=-69.0 ; p<0.001\right)$. Furthermore, it appeared that the eticlopride-induced increase in S-7E animals was more pronounced in $\mathrm{PV}-$ than $\mathrm{PV}+$ pallidal neurons. Although $\mathrm{GAD}_{67}$ mRNA levels were found not to differ between $\mathrm{PV}+$ and $\mathrm{PV}-$ neurons in the S-7V condition, the elevation in $\mathrm{GAD}_{67}$ mRNA in the S-7E condition was significantly greater in $\mathrm{PV}-$ pallidal neurons than in $\mathrm{PV}+$ pallidal neurons $\left[F_{(1,7)}=283.2 ; p<\right.$ $0.001]$.

\section{Discussion}

These findings demonstrate that the PV+ and PV - neurons of the rodent GP are influenced in qualitatively similar ways by 6-OHDA-induced nigrostriatal injury, repeated D2 antagonist administration, and STN lesions. Overall, 6-OHDA lesion or D2 antagonist administration markedly increased $\mathrm{GAD}_{67}$ mRNA in both PV + and $\mathrm{PV}-$ pallidal neurons. However, after either 6-OHDA or D2 antagonist treatment, the increase in $\mathrm{GAD}_{67}$ mRNA was more pronounced in $\mathrm{PV}-$ than $\mathrm{PV}+$ pallidal neurons. Although other investigators have reported increased pallidal $\mathrm{GAD}_{67}$ mRNA after nigral 6-OHDA lesion or repeated D2-class antagonist injections (Kincaid et al., 1992; Soghomonian and Chesselet, 1992; Delfs et al., 1995a), this represents the first report of $\mathrm{GAD}_{67}$ mRNA regulation in these two cell populations.

These experiments also demonstrate that the STN lesion decreased $\mathrm{GAD}_{67}$ mRNA levels in both PV+ and $\mathrm{PV}-$ pallidal neurons. In contrast to the influences of 6-OHDA lesion or eticlopride administration, the impact of the STN lesion on pallidal $\mathrm{GAD}_{67}$ mRNA expression was greater for the $\mathrm{PV}+$ than $\mathrm{PV}-$ neurons

\section{Pallidal $\mathrm{GAD}_{67} \mathrm{mRNA}$ after nigrostriatal lesion or repeated D2 antagonist: functional implications}

In the basal ganglia, changes in $\mathrm{GAD}_{67}$ mRNA expression correlate with increased GAD protein levels, electrophysiological ac-
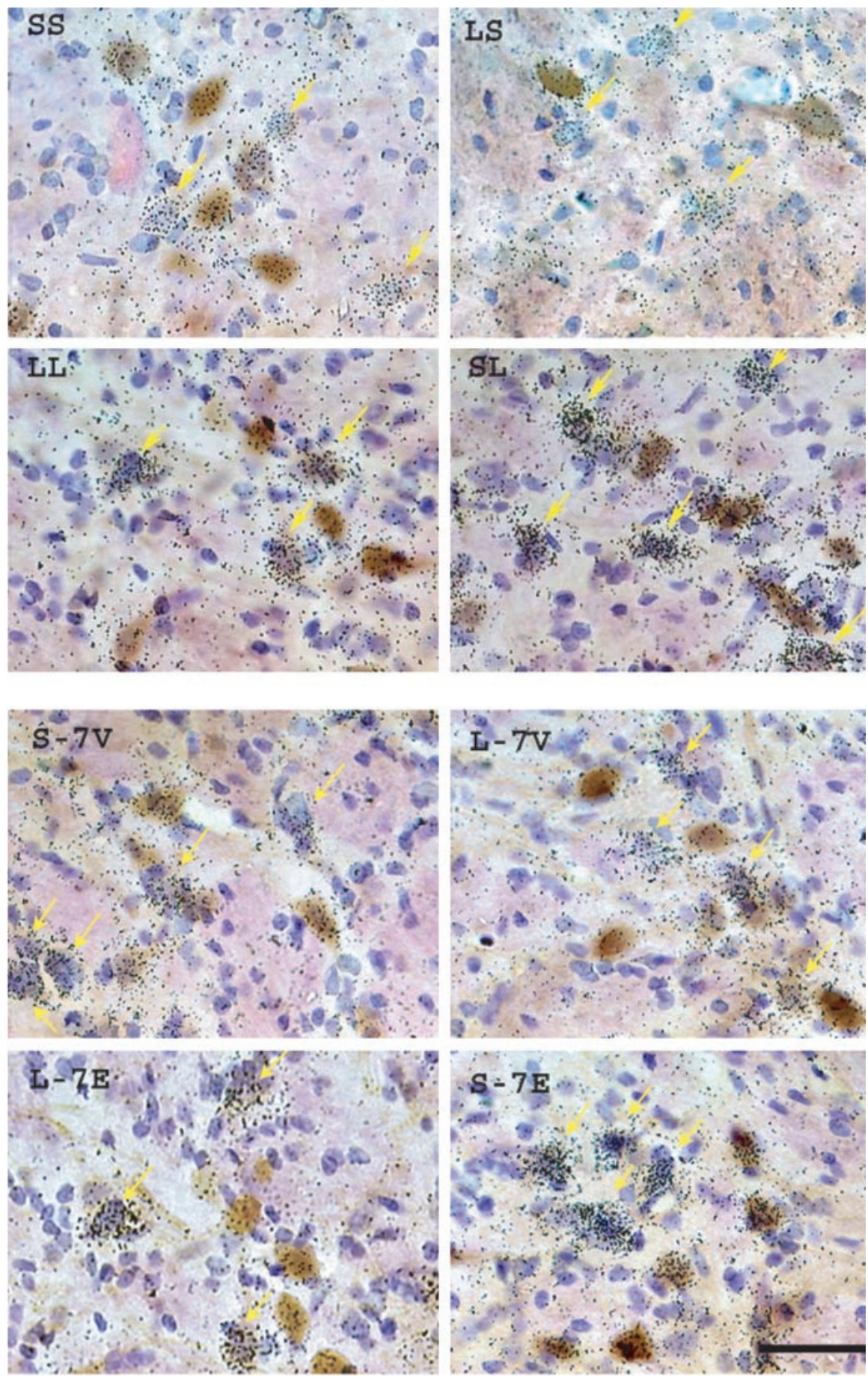

Figure 6. Photomicrographs of $\mathrm{GAD}_{67} \mathrm{mRNA}$ in PV + (brown cells) and PV - (yellow arrows) in neurons of the GP of SS, LS, LL, and $S L$ animals and in the GP of S-7V, L-7V, L-7E, and S-7E animals. Scale bar, $50 \mu \mathrm{m}$

tivity, and compensatory downregulation of GABA receptors (Segovia et al., 1990, 1991; Chada et al., 2000). In other systems (e.g., cerebellum and hippocampus), changes in $\mathrm{GAD}_{67} \mathrm{mRNA}$ expression correlate with increased GAD protein in terminals, increased GABA release, and increases in firing rates of GABAergic neurons (Litwak et al., 1990; Drengler and Oltmans, 1993; Falkenberg et al., 1997). Therefore, although the increase in the $\mathrm{GAD}_{67}$ transcript does not necessarily predict a linear increase in GAD protein levels and subsequent GABA release, the increases in $\mathrm{GAD}_{67}$ mRNA described here are likely to correspond to increased GABAergic transmission within GP neurons. 




Figure 7. Combined STN and 6-OHDA lesions interact to differentially regulate $\mathrm{GAD}_{67} \mathrm{mRNA}$ expression in PV + and PV - GP neurons. * , Significant differences compared with corresponding cell types in Sham + Sham controls. $\diamond$, Significantly increased $\mathrm{GAD}_{67}$ mRNA levels compared with PV + GP neurons for corresponding treatment. The dashed line represents the approximate control levels for comparison purposes; $n=8$ for all groups.

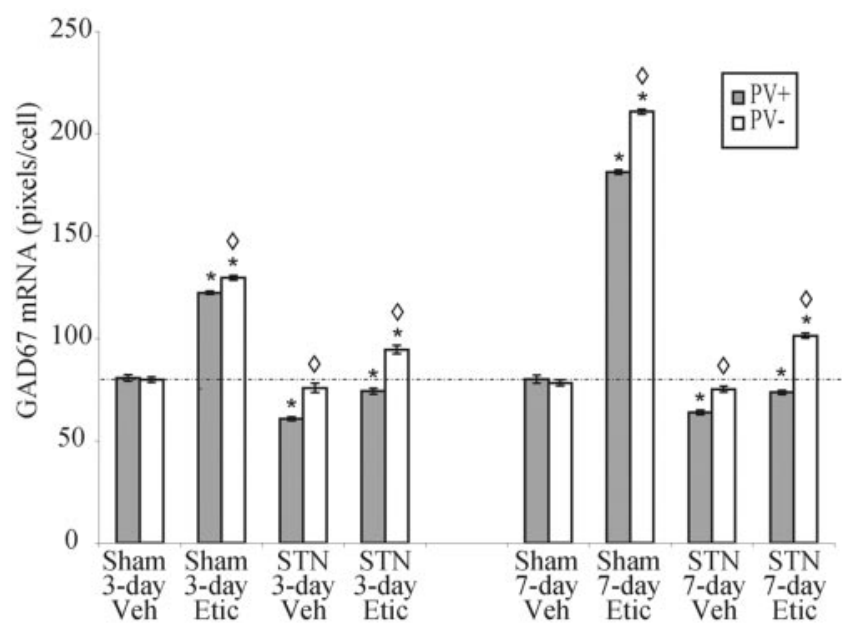

Figure 8. STN and repeated $D 2$ antagonist administration interact to differentially regulate $\mathrm{GAD}_{67}$ mRNA expression in PV + and PV - GP neurons. *, Differences from corresponding cell types in sham vehicle (Veh) groups. $\diamond$, Significantly increased levels of $\mathrm{GAD}_{67} \mathrm{mRNA}$ compared with PV + GP neurons within groups. The dashed line indicates approximate control levels for comparison purposes; $n=8$ for all groups. Etic, Eticlopride.

Accordingly, the present results support the proposal that 6-OHDA lesion or D2 antagonist administration triggers a series of events beginning with disinhibition of striatopallidal neurons and resulting in increased subthalamopallidal activity (Chesselet and Delfs, 1996). Increased STN activity, in turn, can result in GP burst firing (Ni et al., 2000) and enhanced GP $\mathrm{GAD}_{67} \mathrm{mRNA}$ expression levels. In addition, our results suggest that the DA cell lesions or D2 antagonist administration have a second influence, to remove a direct dopaminergic influence on GP neurons. Intrapallidal DA appears normally to suppress gene expression preferentially in PV - neurons through D2-class receptors (Billings and Marshall, 2003).

The similar effects of 6-OHDA and D2 antagonist administration indicate that the loss of DA neurons influences GP $\mathrm{GAD}_{67}$ mRNA primarily through D2-class, not D1-class, receptors. Administration of the D1-class antagonist SCH-23390 for 3, 7, or
$21 \mathrm{~d}$ did not increase $\mathrm{GAD}_{67}$ mRNA in GP neurons. To the contrary, a small decline was observed after $7 \mathrm{~d}$ of treatment. Because a D1 autoradiographic signal, but not D1 mRNA, is found in the GP, pallidal D1 receptors may be located on terminals of striatal and subthalamic neurons (Fremeau et al., 1991; Flores et al., 1999). An influence of D1 antagonist on glutamate release from subthalamopallidal terminals might explain the observed decrease in GP GAD 67 mRNA expression.

\section{Neuron population specificity of effects of nigrostriatal lesion} or repeated D2 antagonist

Previous work demonstrated a differential regulation of neurochemical markers by DA in PV + and PV - GP neurons. Systemic or local application of a D2-class antagonist induces Fos almost exclusively within PV - pallidal neurons (Ruskin and Marshall, 1997; Billings and Marshall, 2003). PPE mRNA, which seldom colocalizes with PV and is found predominantly in pallidostriatal neurons, also increases after 6-OHDA lesion or repeated D2-class antagonist administration (Schuller et al., 1999). DA D 2 receptor mRNA occurs at higher levels in PPE mRNA-containing (PPE+) pallidal neurons, suggesting that this population of $\mathrm{PPE}+/ \mathrm{PV}-$ neurons may be more sensitive to alterations in pallidal DA tone (Hoover and Marshall, 2002).

Electrophysiological recordings also indicate that DA may have differing effects on pallidal neuron populations. Microiontophoretic application of DA into the GP causes both increases and decreases in cell firing rates (Bergstrom and Walters, 1984; Napier et al., 1991; Kelland et al., 1995).

In animals receiving the D2-class antagonist eticlopride, an interesting time course of altered $\mathrm{GAD}_{67}$ mRNA expression emerged. In both neuron populations, expression levels increased initially and then returned toward baseline (see Fig. 4). The population difference in $\mathrm{GAD}_{67}$ expression was emerging after $3 \mathrm{~d}$ and was completely developed after $7 \mathrm{~d}$ of eticlopride administration. After $21 \mathrm{~d}$ of treatment, overall $\mathrm{GAD}_{67}$ mRNA levels were lower than at $7 \mathrm{~d}$, but the population difference was undiminished. Thus, it seems that pallidal $\mathrm{GAD}_{67} \mathrm{mRNA}$ levels are initially upregulated but are later normalized or even decreased below baseline (Mercugliano et al., 1992; Delfs et al., 1995; Mavridis and Besson, 1999). This time course contrasts with that observed after 6-OHDA-induced lesion of the dopaminergic neurons, in which the $\mathrm{GAD}_{67} \mathrm{mRNA}$ upregulation was the same at 5 and $21 \mathrm{~d}$ postoperatively.

\section{Dual processes by which DA and STN inputs regulate GP $\mathrm{GAD}_{67}$ mRNA}

In all experiments, $\mathrm{GAD}_{67} \mathrm{mRNA}$ expression in the GP PV + and $\mathrm{PV}-$ neurons of sham lesion or vehicle-treated controls did not differ. Although the direction of $\mathrm{GAD}_{67}$ mRNA expression changes was similar in $\mathrm{PV}+$ and $\mathrm{PV}-$ neurons after either 6-OHDA lesion alone or STN lesion alone, the effects of the 6-OHDA lesion (or D2 antagonist treatment) were greater for the $\mathrm{PV}-$ cells than the PV + cells, whereas the effects of the STN lesion were greater for the PV + than PV - neurons (Fig. 9). This double dissociation, in addition to the finding that the direction of changes in $\mathrm{GAD}_{67}$ mRNA expression of the two cell populations differed after combined 6-OHDA and STN lesions, argues for the distinctiveness of $\mathrm{GAD}_{67}$ mRNA regulation in $\mathrm{PV}+$ and PV - GP neurons. This suggests that the influences of dopamine on pallidal gene expression occur through at least two processes: one involving the activation of STN inputs to the GP neurons and a second process involving the removal of nigropallidal dopamine (D2-class) transmission. We propose that the elevation of 


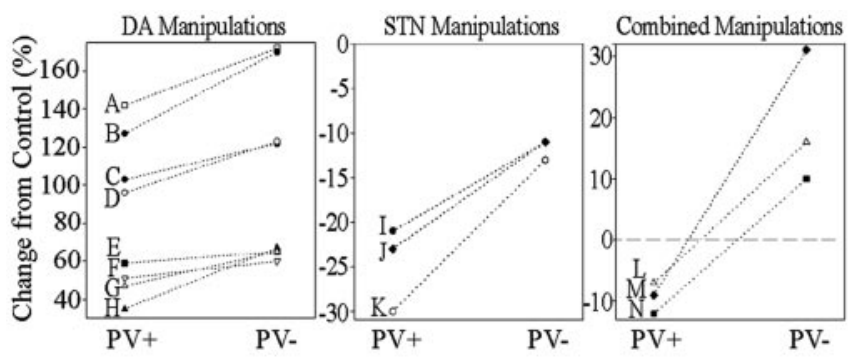

Figure 9. Combined DA and STN manipulations indicate a double dissociation of the effects of these treatments on PV + and PV - GP neurons. DA manipulations: $A, 7$ d eticlopride; $B$, sham STN and 7 d eticlopride; C, 5 d 6-OHDA lesion; D, 21 d 6-OHDA lesion; $E$, 3 d eticlopride; $F$, sham STN and 3 deticlopride; $G$, sham STN and 6-OHDA lesion; $H, 21$ deticlopride. STN manipulations: I, STN lesion and $7 \mathrm{~d}$ vehicle; J, STN lesion and sham 6-OHDA lesion; K, STN lesion and $3 \mathrm{~d}$ vehicle. Combined manipulations: $L$, STN lesion and $3 \mathrm{~d}$ eticlopride; $M$, STN lesion and $7 \mathrm{~d}$ eticlopride; N, STN lesion and 6-OHDA lesion.

$\mathrm{GAD}_{67}$ mRNA in PV + pallidal neurons depends exclusively on STN activation, whereas the increase in PV - neurons in this transcript depends on both processes. The rationale for proposing that decreased pallidal DA transmission preferentially affects the gene expression of PV- GP neurons was cited above.

It remains unclear what drives the increase in $\mathrm{GAD}_{67} \mathrm{mRNA}$ expression in PV - neurons of the GP in animals with an STN lesion. Although the STN provides the greatest excitatory input to the GP, other areas may contribute to pallidal gene expression. For example, the parafascicular nucleus projects directly to the GP (Kincaid et al., 1991; Deschenes et al., 1996; Orieux et al., 2000; Gonzalo et al., 2002) and may importantly affect pallidal neuronal activity independently of STN inputs (Mouroux et al., 1997). Thus, parafascicular inputs to the GP may account for the remaining elevation in $\mathrm{GAD}_{67}$ mRNA expression levels in 6-OHDA- (or eticlopride)-treated, STN-lesioned animals.

\section{Implications for basal ganglia circuit function of changes in GP GAD 67 mRNA expression}

The GP is a highly heterogeneous structure, with population distinctions based on electrophysiological characteristics, projection target, chemical phenotype, receptor transcript density, and dendritic branching patterns (Park et al., 1982; Napier et al., 1991; Kita and Kitai, 1994; Nambu and Llinas, 1994; Rajakumar et al., 1994; Kelland et al., 1995; Ruskin and Marshall, 1997; Hoover and Marshall, 1999, 2002; Sato et al., 2000). The separation of pallidal neurons based on chemical markers has proven to be particularly useful because such markers correlate with projection targets. Tracer studies indicate that most pallidal neurons that are retrogradely labeled from the STN or substantia nigra pars reticulata contain PV, whereas most pallidal neurons retrogradely labeled from the striatum lack PV (Ruskin and Marshall, 1997; Hoover and Marshall, 1999, 2002). It may be that most GP neurons containing PV project to "downstream" structures, and a few project to the striatum; alternatively, most or all PV + GP neurons may project both to the striatum and downstream structures, with the density of projections to each target differing. In either case, the patterns of projections from the PV + and PVcell populations are distinct.

Pallidostriatal neurons appear to terminate primarily on PV--containing striatal interneurons (Bevan et al., 1998), which in turn powerfully inhibit striatofugal projection neurons (Koos and Tepper, 1999). Striatal PV + interneurons integrate information from many cortical areas (Bennett and Bolam, 1994; Ramanathan et al., 2002) as well as from other interneurons through dendritic gap junctions (Kita and Kitai, 1990; Koos and Tepper, 1999). Striatal PV + interneurons receive multiple synaptic contacts from a single cortical neuron (Ramanathan et al., 2002), and the $\mathrm{PV}+$ striatal interneurons may be more responsive to cortical inputs than are striatal projection neurons (Parthasarathy and Graybiel, 1997; Stern et al., 1997; Ramanathan et al., 2002). Together, these observations indicate that pallidostriatal neurons are critically positioned to regulate striatal activity. Indeed, lesion-induced alterations in activity of the pallidostriatal projection might explain the decrease in striatal $\mathrm{GAD}_{67}$ mRNA expression observed in 6-OHDA-lesioned rats (Soghomonian et al., 1992). Under conditions of D2 antagonist treatment or nigrostriatal injury, activation of inhibitory pallidostriatal neurons could result in the subsequent disinhibition of striatal projection neurons, exacerbating hypokinetic symptoms. Thus, the nigropallidal projection provides an important target in the study of the genesis and expression of motor symptoms in animal models of Parkinson's disease.

\section{References}

Bergstrom DA, Walters JR (1984) Dopamine attenuates the effects of GABA on single unit activity in the globus pallidus. Brain Res 310:23-33.

Bevan MD, Clarke NP, Bolam JP (1997) Synaptic integration of functionally diverse pallidal information in the entopeduncular nucleus and subthalamic nucleus in the rat. J Neurosci 17:308-324.

Bevan MD, Booth PA, Eaton SA, Bolam JP (1998) Selective innervation of neostriatal interneurons by a subclass of neuron in the globus pallidus of the rat. J Neurosci 18:9438-9452.

Bennett BD, Bolam JP (1994) Synaptic input and output of parvalbuminimmunoreactive neurons in the neostriatum of the rat. Neuroscience 62:707-719.

Billings LM, Marshall JF (2003) D2 antagonist-induced c-fos in an identified subpopulation of globus pallidus neurons by a direct intrapallidal action. Brain Res 964:237-243.

Chada A, Dawson LG, Jenner PG, Duty S (2000) Effect of unilateral 6-hydroxydopaminelesions of the nigrostriatal pathway on GABAA receptor subunit gene expression in the rodent basal ganglia and thalamus. Neuroscience 95:119-126.

Chesselet MF, Delfs JM (1996) Basal ganglia and movement disorders: an update. Trends Neurosci 19:417-422.

Cooper AJ, Stanford IM (2000) Electrophysiological and morphological characteristics of three subtypes of rat globus pallidus neurone in vitro. J Physiol (Lond) 527:291-304.

Delfs JM, Anegawa NJ, Chesselet MF (1995a) Glutamate decarboxylase messenger RNA in rat pallidum: comparison of the effects of haloperidol, clozapine and combined haloperidol-scopolamine treatments. Neuroscience 66:67-80.

Delfs JM, Ciaramitaro VM, Parry TJ, Chesselet MF (1995b) Subthalamic nucleus lesions: widespread effects on changes in gene expression induced by nigrostriatal dopamine depletion in rats. J Neurosci 15:6562-6575.

Deschenes M, Bourassa J, Doan VD, Parent A (1996) A single-cell study of the axonal projections arising from the posterior intralaminar thalamic nuclei in the rat. Eur J Neurosci 8:329-343.

Drengler SM, Oltmans GA (1993) Rapid increases in cerebellar Purkinje cell glutamic acid decarboxylase (GAD67) mRNA after lesion-induced increases in cell firing. Brain Res 615:175-179.

Falkenberg T, Lindefors N, O'Connor WT, Zachrisson O, Camilli F, Ungerstedt U (1997) GABA release and GAD67 mRNA expression in rat hippocampus following entorhinal cortex activation. Mol Brain Res 48:413-416.

Fallon JH, Moore RY (1978) Catecholamine innervation of the basal forebrain. IV. Topography of the dopamine projection to the basal forebrain and neostriatum. J Comp Neurol 180:545-580.

Floran B, Floran L, Sierra A, Aceves J (1997) D2 receptor-mediated inhibition of GABA release by endogenous dopamine in the rat globus pallidus. Neurosci Lett 237:1-4.

Flores G, Liang JJ, Sierra A, Martinez-Fong D, Quirion R, Aceves J, Srivastava LK (1999) Expression of dopamine receptors in the subthalamic nucleus of the rat: characterization using reverse transcriptase-polymerase chain reaction and autoradiography. Neuroscience 91:549-556. 
Fremeau Jr RT, Duncan GE, Fornaretto MG, Dearry A, Gingrich JA, Breese GR, Caron MG (1991) Localization of D1 dopamine receptor mRNA in brain supports a role in cognitive, affective, and neuroendocrine aspects of dopaminergic neurotransmission. Proc Natl Acad Sci USA 88:3772-3776.

Gonzalo N, Lanciego JL, Castle M, Vazquez A, Erro E, Obeso JA (2002) The parafascicular thalamic complex and basal ganglia circuitry: further complexity to the basal ganglia model. Thalamus Relat Syst 1:341-348.

Hoover BR, Marshall JF (1999) Population characteristics of preproenkephalin mRNA-containing neurons in the globus pallidus of the rat. Neurosci Lett 265:199-202.

Hoover BR, Marshall JF (2002) Further characterization of preproenkephalin mRNA-containing cells in the rodent globus pallidus. Neuroscience 111:111-125.

Kelland MD, Soltis RP, Anderson LA, Bergstrom DA, Walters JR (1995) In vivo characterization of two cell types in the rat globus pallidus which have opposite responses to dopamine receptor stimulation: comparison of electrophysiological properties and responses to apomorphine, dizocilpine and ketamine anesthesia. Synapse 20:338-350.

Kincaid AE, Penney Jr JB, Young AB, Newman SW (1991) The globus pallidus receives a projection from the parafascicular nucleus in the rat. Brain Res 553:18-26.

Kincaid AE, Albin RL, Newman SW, Penney Jr JB, Young AB (1992) 6-Hydroxydopamine lesions of the nigrostriatal pathway alter the expression of glutamate decarboxylase messenger RNA in rat globus pallidus projection neurons. Neuroscience 51:705-718.

Kita H (1994) Parvalbumin-immunopositive neurons in rat globus pallidus: a light and electron microscopic study. Brain Res 657:31-41.

Kita H, Kitai ST (1990) Amygdaloid projections to the frontal cortex and the striatum in the rat. J Comp Neurol 298:40-49.

Kita H, Kitai ST (1994) The morphology of globus pallidus projection neurons in the rat: an intracellular staining study. Brain Res 636:308-319.

Koos T, Tepper JM (1999) Inhibitory control of neostriatal projection neurons by GABAergic interneurons. Nat Neurosci 2:467-472.

Lindvall O, Björklund A (1979) Dopaminergic innervation of the globus pallidus by collaterals from the nigrostriatal pathway. Brain Res 172:169-173.

Litwak J, Mercugliano M, Chesselet MF, Oltmans GA (1990) Increased glutamic acid decarboxylase (GAD) mRNA and GAD activity in cerebellar Purkinje cells following lesion-induced increases in cell firing. Neurosci Lett 116:179-183.

Mavridis M, Besson MJ (1999) Dopamine-opiate interaction in the regulation of neostriatal and pallidal neuronal activity as assessed by opioid precursor peptides and glutamate decarboxylase messenger RNA expression. Neuroscience 92:945-966.

Mercugliano M, Saller CF, Salama AI, U’Prichard DC, Chesselet MF (1992) Clozapine and haloperidol have differential effects on glutamic acid decarboxylase mRNA in the pallidal nuclei of the rat. Neuropsychopharmacology 6:179-187.

Mouroux M, Hassani OK, Feger J (1997) Electrophysiological and Fos immunohistochemical evidence for the excitatory nature of the parafascicular projection to the globus pallidus. Neuroscience 81:387-397.

Nambu A, Llinas R (1994) Electrophysiology of globus pallidus neurons in vitro. J Neurophysiol 72:1127-1139.

Napier TC, Simson PE, Givens BS (1991) Dopamine electrophysiology of ventral pallidal/substantia innominata neurons: comparison with the dorsal globus pallidus. J Pharmacol Exp Ther 258:249-262.

Ni Z, Bouali-Benazzouz R, Gao D, Benabid AL, Benazzouz A (2000)
Changes in the firing pattern of globus pallidus neurons after the degeneration of nigrostriatal pathway are mediated by the subthalamic nucleus in the rat. Eur J Neurosci 12:4338-4344.

Oertel WH, Mugnaini E (1984) Immunocytochemical studies of GABAergic neurons in rat basal ganglia and their relations to other neuronal systems. Neurosci Lett 47:233-238.

Orieux G, Francois C, Feger J, Yelnik J, Vila M, Ruberg M, Agid Y, Hirsch EC (2000) Metabolic activity of excitatory parafascicular and pedunculopontine inputs to the subthalamic nucleus in a rat model of Parkinson's disease. Neuroscience 97:79-88.

Park MR, Falls WM, Kitai ST (1982) An intracellular HRP study of the rat globus pallidus. I. Responses and light microscopic analysis. J Comp Neurol 211:284-294.

Parthasarathy HB, Graybiel AM (1997) Cortically driven immediate-early gene expression reflects modular influence of sensorimotor cortex on identified striatal neurons in the squirrel monkey. J Neurosci 17:2477-2491.

Paxinos G, Watson C (1998) The rat brain in stereotaxic coordinates. New York: Academic.

Rajakumar N, Rushlow W, Naus CC, Elisevich K, Flumerfelt BA (1994) Neurochemical compartmentalization of the globus pallidus in the rat: an immunocytochemical study of calcium-binding proteins. J Comp Neurol 346:337-348

Ramanathan S, Hanley JJ, Deniau JM, Bolam JP (2002) Synaptic convergence of motor and somatosensory cortical afferents onto GABAergic interneurons in the rat striatum. J Neurosci 22:8158-8169.

Ruskin DN, Marshall JF (1997) Differing influences of dopamine agonists and antagonists on Fos expression in identified populations of globus pallidus neurons. Neuroscience 81:79-92.

Sato F, Lavallee P, Levesque M, Parent A (2000) Single-axon tracing study of neurons of the external segment of the globus pallidus in primate. J Comp Neurol 417:17-31.

Schuller JJ, Billings LM, Marshall JF (1999) Dopaminergic modulation of pallidal preproenkephalin mRNA. Brain Res Mol Brain Res 69:149-153.

Segovia J, Tillakaratne NJ, Whelan K, Tobin AJ, Gale K (1990) Parallel increases in striatal glutamic acid decarboxyase activity and mRNA levels in rats with lesions of the nigrostriatal pathway. Brain Res 529:345-348.

Segovia J, Armstrong DM, Benzing WC, Hornby PJ (1991) Striatal glutamic acid decarboxylase immunoreactivity is increased after dopaminergic deafferentation: densitometric analysis. Neurosci Lett 122:252-256.

Shammah-Lagnado SJ, Alheid GF, Heimer L (1996) Efferent connections of the caudal part of the globus pallidus in the rat. J Comp Neurol 376:489-507.

Smith Y, Bolam JP (1990) The output neurones and the dopaminergic neurones of the substantia nigra receive a GABA-containing input from the globus pallidus in the rat. J Comp Neurol 296:47-64.

Soghomonian JJ, Chesselet MF (1992) Effects of nigrostriatal lesions on the levels of messenger RNAs encoding two isoforms of glutamate decarboxylase in the globus pallidus and entopeduncular nucleus of the rat. Synapse 11:124-133.

Soghomonian JJ, Gonzales C, Chesselet MF (1992) Messenger RNAs encoding glutamate-decarboxylases are differentially affected by nigrostriatal lesions in subpopulations of striatal neurons. Brain Res 576:68-79.

Staines WA, Atmadja S, Fibiger HC (1981) Demonstration of a pallidostriatal pathway by retrograde transport of HRP-labeled lectin. Brain Res 206:446-450.

Stern EA, Kincaid AE, Wilson CJ (1997) Spontaneous subthreshold membrane potential fluctuations and action potential variability of rat corticostriatal and striatal neurons in vivo. J Neurophysiol 77:1697-1715. 